\section{Makhfuzakhon Shamsieva \\ researcher, \\ National University of Uzbekistan cool.jumaboyev@mail.ru}

\author{
p-ISSN: 2308-4944 (print) e-ISSN: 2409-0085 (online) \\ Year: 2017 Issue: $01 \quad$ Volume: 45 \\ Published: $30.01 .2017 \quad$ http://T-Science.org
}

SECTION 13. Geography. History. Oceanology. Meteorology.

\title{
ACTIVITIES CARRIED OUT BY NON-GOVERNMENTAL ORGANIZATIONS ON IMPLEMENTATION OF THE PRINCIPLE "FROM A STRONG STATE TO A STRONG CIVIL SOCIETY" (IN THE CASE OF WOMEN'S NON-GOVERNMENTAL ORGANIZATIONS)
}

\begin{abstract}
This work sheds a light on the measures taken on purpose of building a democratic legal and strong sitizen-ship society by non-state and non-profit organizations that are functioning in Uzbekistan.

Key words: sitizenship society,non-state and non-profir organizations,small scale business, private entrepreneurship, project, financial stability, choice.

Language: English

Citation: Shamsieva M (2017) ACTIVITIES CARRIED OUT BY NON-GOVERNMENTAL ORGANIZATIONS ON IMPLEMENTATION OF THE PRINCIPLE "FROM A STRONG STATE TO A STRONG CIVIL SOCIETY”. IN THE CASE OF WOMEN'S NON-GOVERNMENTAL ORGANIZATIONS. ISJ Theoretical \& Applied Science, 01 (45): 52-55.

Soi: http://s-o-i.org/1.1/TAS-01-45-8 Doi: crossef https://dx.doi.org/10.15863/TAS.2017.01.45.8
\end{abstract}

\section{Introduction}

Since the date of independence important reforms are being step-by-step implemented on building ademocratic state and strong civil society. This process has created a comfortable zone for the rapid development of civil society institutions and non-governmental organizations, which are the main part of civil society. Nowadays the public and civil control institution has become one of the important tools of providing efficient link between the public and government, determination of people's mood and their attitude to the changes in the country. A number of organizations on human rights such as Ombudsman, National Center of Human rights, Public center of Social opinion, The monitoring institution of actual law documents are functioning in the country. As the role of non-profit organizations in the system of civil society institutions is matchless, they have managed to become an important factor in protecting human rights, freedom and their legitimate interests. They are creating conditions for the realization of people's potential, improving their social-economic activity and legal culture, and assisting in providing a balance of interests in society.

\section{Materials and Methods}

The adoption of more than 200 legislative acts on improving the role and importance of civil society institutions, provision of their independent activities, protection of their rights and legitimate interests, improving their organizational, legal, financial and technical support indicates that the principle "From a strong state to a strong civil society" is being consistently implemented in our country. It should be noted that a democratic independent system of forming a source for financing non-profit organizations and other civil society institutions has been created in Uzbekistan [1].

Nowadays non-profit organizations are covering all fields of the society. Their total number has now reached 8417. And this shows that during the last five years the number of non-profit organizations have increased by 64.5 percent [2].

The establishment and development of public organizations in Uzbekistan, in particular, women's non-profit organizations do not have a long history. According to the development of the communication between those organizations and the government this history can be divided into three phases:

First phase includes the years 1991-1995. This is a development period of organizations, so it wasn't yet confessed by the government. In this step total of 
ten non-profit women's organizations were established.

The second phase includes the years 19952004, and has been a period of understanding how solving the country's development problems together were essential. In this phase the Presidential decree of the Republic of Uzbekistan dated March 2, 1995 “On measures of improving women's role in the state and social construction of the Republic of Uzbekistan", and the Presidential decree dated May 25, 2004 "On additional measures of supporting Women's committee of Uzbekistan" have increased the number of women's organizations and created a cooperation between state organizations. In these years more than a hundred non-profit organizations have been established.

The third phase started in 2005, and includes the current processes. The Presidential decree of the Republic of Uzbekistan dated July 23, 2005 "On measures of supporting the development of civil society institutions" is providing an increase in the number of non-profit organizations as it protects democratic values, human rights, freedom and legitimate interests. During these historical phases organizational, legal, financial and technical conditions have been created to form the "third sector". It has become a legal basis for the operation of non-profit organizations that are engaged in women's issues, taking into account that women contain more than a half of Uzbekistan's population. By the way, their role has increased in legal support to citizens, improving their political mentality, working with women and the youth, employment, supporting the people in need of assistance and other spheres [3]. Especially, the number of non-profit organizations concerning the development of private entrepreneurship and farming is increasing year after year. 22.1 percent of currently operating non-profit organizations has specialized in this area [4].

Conditions created for small business and private entrepreneurship — allowing procedures have been reduced to more than 160 units or 44 percent, 19 types or 25 percent of activities requiring licensing, the volume and periodicity of statistical, tax and financial reports presented by entrepreneurs to state authorities have been decreased by $1.5-2$ times. These reforms have increased the contribution of the members of this sphere to the Gross Domestic Product of the country up to 54 percent. This number is 20 percent in Russia, 50 percent in the USA and 60 percent in Great Britain accordingly [5].

It should be noted that a unique model of financial support on attracting women to entrepreneurship has been created. The fact that nowadays 35 percent of entrepreneurs are women is a clear confirmation of systematic and consistent work in terms of accelerating their economic activity and employment.
In 2009-2015 by the Public fund of OliyMajlis of the Republic of Uzbekistan on supporting nonprofit organizations and other civil society institutions 969 social projects [6] - "My profession - my prosperous life, happiness and wealth" project ofthe "Businesswoman" Association of Business Women of Uzbekistan in Bukhara region Jondor department, "Directing unemployed women and local youth to entrepreneurship and their employment in remote villages" project of "Support for children and families" Association in Yangiqurgan district department, "Supporting the young girls of low-income families in achieving a profession and employment in Qushkupir district villages" project of "Fount of love" social and legal support center of women and their families in Khorazm region, "Businesswoman, prosperous family, stable society" project of "Woman entrepreneurs and businesswomen" public association in Tashkent, "Assistance in the development of family business, private entrepreneurship, outwork, folk crafts and other types of businesses in remote rural areas" project of "Women's Council" Republican public association have solved the issues on directing women to small business and entrepreneurship, as well as their employment.

Today, while our country is rapidly developing, the role of non-governmental sectors is growing steadily. We can witness it by women's non-profit organizations operating throughout the Republic. In Khorazm region, by "Interknowledge" non-profit organization under OliyMajlis and the public fund of supporting other civil society institutions"Providing the employment of the youth and women by developing their business initiatives" project in 2009 , "Setting a public control of the implementation of legislation by the administration officials by improving the opportunities of non-profit organizations, self-governing bodies and the representatives of mass media" project in 2012 were recognized as winners. In 2014-2015, 60 school students were taught to prepare social video clips. Winners of the competition were identified on the basis of the project. The social clips "Urganch city: yesterday and today", "History of Khorazm" and "Ecology" which reflect our national values and history were announced as winners [7].

The non-profit organization "Shining soul" which operates since 2007 in Fergana is actively participating in Public Fund contest until the present day. The Center's "Resolving family disputes" project has been awarded a grant by the World Bank representation in the Republic of Uzbekistan in 20092010. In 2011-2012 the "New profession - new opportunity" project, the "Strong family - a guarantee of the country's future" project in 2016 have won the competition of the Fund of supporting 
non-profit organizations under the OliyMajlis of the Republic [8].

The "Directing young family women and female college graduates to entrepreneurship and improving their professional qualification in Kokand suburban districts" project of "Health plus ecology" public association was financed by the Public Fund, so training courses for girls and women of lowincome and unemployed families were created. A "Teacher-student" tradition was launched by qualified specialists. The main goal of the project was to aid women achieve financial stability by establishing and developing their family business. In order to provide the endurance of the project the organization of paid consulting services of "Business incubator" club has been planned [9].

The "Mehrjon" non-profit organization, which is operating in Fergana, has managed to launch many social projects. Particularly, the "Good luck" project on employment in 2010, "Legal basis of improving the social activeness of rural women" project in 2011, "Improving the social activeness of the youth in the society" project in 2012, "A way to business" project in 2014-2015 have played a great role in improving the financial, political, legal literacy of women from low-income families, as well as teaching them professions in two directions continued by their employment. "Healthy youth" project in 2009, "The new generation chooses healthy lifestyle" project in 2011-2012, "Prevention of HIV / AIDS and other infectious diseases among women living in rural areas of Quvasoy city" project in 2013-2014 have been launched by the Center in terms of health, and seminars were organized in sports complexes of rural areas in cooperation with "Mahalla" fund intended to educate the youth on the basis of a healthy lifestyle. The seminars have created a condition for the better understanding of the youth about personal hygiene, HIV / AIDS, infectious diseasesand the negative consequences of drug use [10].

Today's period shows that the effective work of non-profit organizations is one of the most necessary conditions of achieving financial stability. The funds allocated by the state budget of OliyMajlis' public fund on supporting the civil society institutions is playing an important role in providing the financial stability of non-profit organizations. In 2008 this number reached 2.1 billion UZS and 10 billion UZS in 2015. This, in turn, shows the sustainable growth of the volume of state financial support directed to "third sector".

The funds allocated from the state budget on supporting the civil society institutions are separated as state subsidies, state social orders and state grants. In particular, the total volume of the state subsidy was 11 billion 510 million UZS in 2011-2015. For 79 projects in the form of state social order more than 8 billion UZS fund was allocated in 2011-2015. The number of non-profit organizations have increased year after year in the grant contests of the public fund, and in 2015 the social projects of non-profit organizations with 3 billion 558 million 700 thousand UZS amount of fund were redirected as a state grant. It is noteworthy that the financed grant projects are leading to the solution of actual economic and social problems, as well as the improvement of financial and technical provision of non-profit organizations.

Another source of the financial stability of "third sector" is the grants of international donors. Only in 2015 with the help of international organization structures: the "Improving the potential of non-profit organizations" project of UNICEF and Uzbekistan non-profit organizations association, "Business forum of Uzbekistan" project of Chamber of Commerce and Industry of Uzbekistan and United Nations Development Program, "Management training program -improving the potential of private entrepreneurs and small enterprise managers" project of Chamber of Commerce and Industry of Uzbekistan and European Union commission, "Supporting the Finance sector of the Republic of Uzbekistan" project of saving fund of Germany on international cooperation, "Expansion of the population's fight against AIDS" project of the Women's committee of Uzbekistan and the global fund of United Nationsdevelopment program on fighting against AIDS, Tuberculosis and Malaria, "Improving the potential of the representatives of Women's committee in structural parts, local consultants and the executive monitoring group members of SEDAW national movement" project of Women's committee of Uzbekistan and UNFPA, "Supporting the implementation of ecological initiatives in the Republic of Uzbekistan" project of Uzbekistan Ecological movement and Projects coordinator in Uzbekistan, "Improving the activeness of non-profit organizations and mass media in developing public control and social partnership" project of Civil society development Institute and Projects coordinator in Uzbekistan were implemented [11].

\section{Conclusion}

We can conclude that as we have aimed to build a legal democratic state and civil society on the basis of economic, social and political reforms carried out in our country, the life itself puts the principle "From a strong state to a strong civil society" to our agenda, for it considers the role of citizens in the country's management as the main priority.

Today, one of the main tasks of the state is preventing any barriers that can block the creation and development of political parties and social movements which reflect the interests of the different layers of the population of Uzbekistan. The barriers in front of non-profit organizations: issues on 


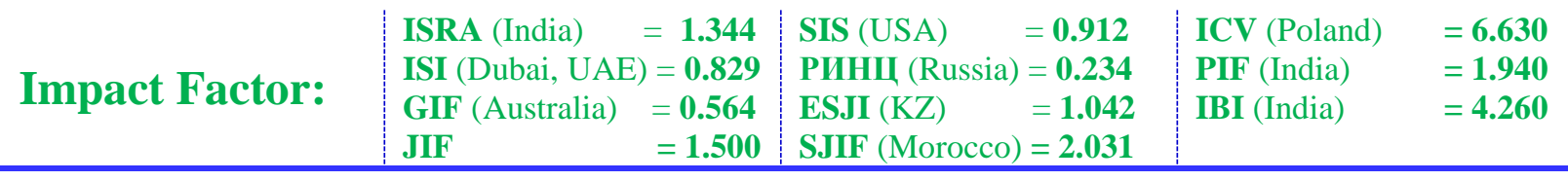

allocating buildings for non-profit organizations; the financial and technical issues in non-profit organizations that are obstructing the attraction of expert staff; the workers of non-profit organizations are not protected by the trade union; poor cooperation between non-profit organizations and other problems as well. As there are barriers the completion of urgent tasks will be difficult.

Each issue shown above requires special care and approach. For their solution it is necessary to improve the cooperation between state and non-profit organizations, as well as developing the ways of cooperation with the international community.

Today, the life itself shows the rightness of the development model chosen by Uzbekistan. It is not a secret that the 25 years' successes and achievements are confessed by advanced countries and international organizations. It is certain that Uzbekistan, by rapidly going through the way of deepened democratic reforms, will take a place among prosperous democratic states.

\section{References:}

1. (2010) Conception of further deepening of democratic reforms in our country and development of civil society. The lecture of the President of the Republic of Uzbekistan I.Karimov in the joint meeting of the Legislative chamber of OliyMajlis and the Senate. // "Xalq so'zi". November 13, 2010. Page 4.

2. (2015) The development of civil society in Uzbekistan.Independent institute of monitoring the formation of civil society.Annual report.//Current archive materials of 2015. Page 11.

3. (2015) Provision of women's interests is the main condition of forming a civil society. //“Xalqso'zi”. September 11, 2015. Page 2.

4. (2015) The development of civil society in Uzbekistan.Independent institute of monitoring the formation of civil society.Annual report. //Current archive materials of 2015. Page 12.

5. Karimov IA (2015) Continuing our way of development on democratic renewal and modernization with determination - our main goal.Tashkent: "Uzbekistan", 2015. Page 14.

6. (2017) Available: http://fundngo.uz (Accessed: 10.01.2017).

7. (2015) 2009-2015 report materials of "Interbilim" non-profit organization in Khorazm region. //current archive.

8. (2016) 2009-2016 report materials of "Qalb nuri" non-profit organization in Fergana region. $/ /$ current archive.

9. (2015) 2009-2015 report materials of "Salomatlik plus Ekologiya" non-profit organization in Fergana region. // current archive.

10. (2015) 2009-2015 report materials of "Mehrjon" non-profit organization in Fergana region. // current archive.

11. (2015) The development of civil society in Uzbekistan.Independent institute of monitoring the formation of civil society.Annual report. //Current archive materials of 2015. Page 12-14. 